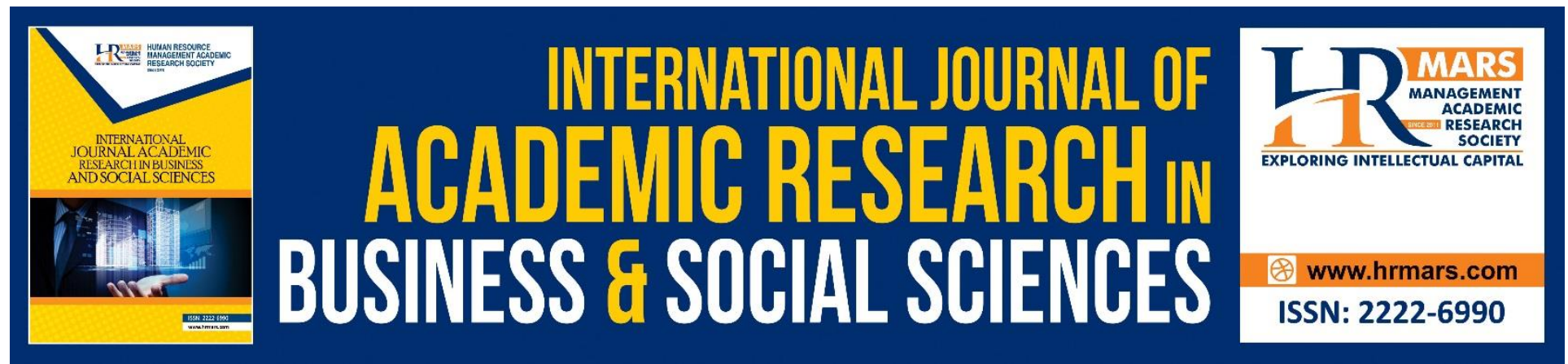

\title{
Exploring the Dimensions of Customer-Based Brand Equity on Firm Performance: A Study of Azam Brand
}

Ahmad Mtengwa Burhan, Mayasa Mussa Kalinga, Mneke Japhary

To Link this Article: http://dx.doi.org/10.6007/IJARBSS/v8-i10/4784

DOI: $10.6007 /$ IJARBSS/v8-i10/4784

Received: 02 Sept 2018, Revised: 16 Oct 2018, Accepted: 28 Oct 2018

Published Online: 09 Nov 2018

In-Text Citation: (Burhan, Kalinga, \& Japhary, 2018)

To Cite this Article: Burhan, A. M., Kalinga, M. M., \& Japhary, M. (2018). Exploring the Dimensions of CustomerBased Brand Equity on Firm Performance: A Study of Azam Brand. International Journal of Academic Research in Business and Social Sciences, 8(10), 851-873.

Copyright: (C) 2018 The Author(s)

Published by Human Resource Management Academic Research Society (www.hrmars.com)

This article is published under the Creative Commons Attribution (CC BY 4.0) license. Anyone may reproduce, distribute, translate and create derivative works of this article (for both commercial and non-commercial purposes), subject to full attribution to the original publication and authors. The full terms of this license may be seen

at: http://creativecommons.org/licences/by/4.0/legalcode

Vol. 8, No. 10, 2018, Pg. 851 - 873

http://hrmars.com/index.php/pages/detail/IJARBSS

JOURNAL HOMEPAGE

Full Terms \& Conditions of access and use can be found at http://hrmars.com/index.php/pages/detail/publication-ethics 


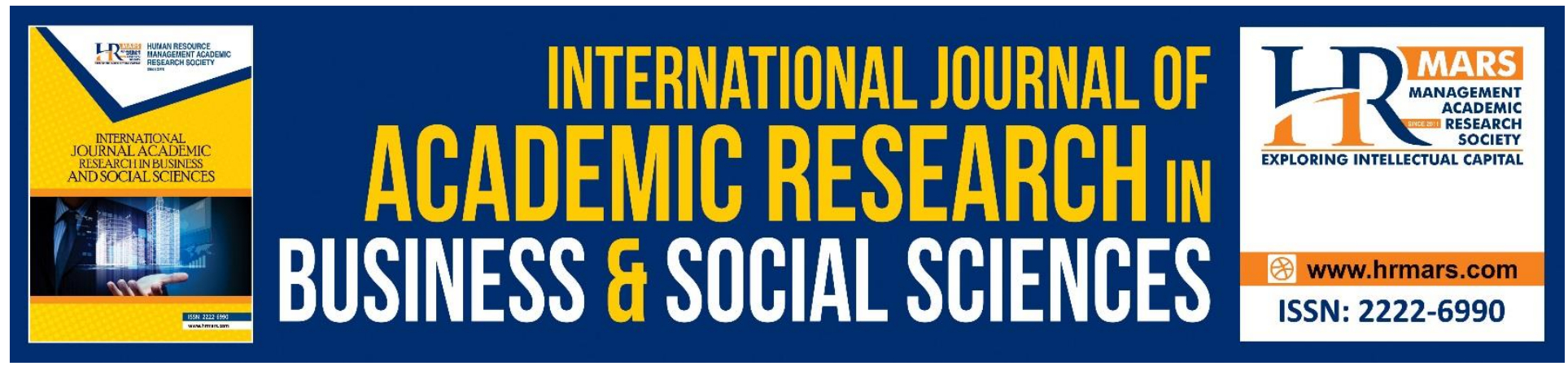

\title{
Exploring the Dimensions of Customer-Based Brand Equity on Firm Performance: A Study of Azam Brand
}

\author{
Dr. Ahmad Mtengwa Burhan \\ Department of Economic Diplomacy, Centre for foreign relations \\ Email: mtengwa@hotmail.com \\ Mayasa Mussa Kalinga \\ Department of Economic Diplomacy, Centre for Foreign Relations \\ Email: maya.kalinga@gmail.com \\ Mneke Japhary \\ Department of Economic Diplomacy, Centre for Foreign Relations
}

\begin{abstract}
Although Tanzania market is deluged with value-for- money brands since decades ago, not all Tanzania brands achieved national recognition. The objective of this research therefore is to develop a valid and reliable model of Tanzania brand equity by assessing the dimensions of the brand equity and its constructs.

Based on 30 constructs, which were compiled from literatures, four variables were included for brand awareness, seventeen variables for brand association, five for perceived quality and four for brand loyalty. Factor Analysis was conducted to identify dimensions of brand equity and its constructs. Principal component Analysis with subsequent rotation (Varimax) was conducted on 30 constructs of a questionnaire. According to the four dimensions proposed by Aaker (1991) in the brand equity literature, a four factor solution that reduced the 30 constructs to four factors was chosen in this study.

The factors produce a Cronbach alpha of 0.96, with Eigen values greater than 1.0. The brand equity constructs with a loading below 0.6 were excluded from further analysis. 14 constructs remained in this study.
\end{abstract}

Keywords: Brand Awareness, Brand Associations, Brand Equity, Perceived Quality, Brand Loyalty, Azam 
INTERNATIONAL JOURNAL OF ACADEMIC RESEARCH IN BUSINESS AND SOCIAL SCIENCES Vol. 8, No. 10, Oct. 2018, E-ISSN: 2222-6990 @ 2018 HRMARS

\section{INTRODUCTION}

For manufacturers and producers of a vast range of products and services, brands are one of the key success factors in achieving competitive advantage through differentiation (Wood, 2000). Brands undoubtedly create added value for both firms and consumers as they play a key role in enhancing the value for both firms and consumers as they play a key role in enhancing the value of products and protecting them from imitation by competitors (Aaker,1991). In fact, "a product is something that is made in a factory; a brand is something that is bought by a customer".

A product can be copied by a competitor; a brand is unique. A product can be quickly outdated; "a successful brand is timeless" (king, cited in Aaker, 1991, p.1). In other words, a strong brand is counted as a valuable company asset. This value, which is commonly referred to as brand equity, has drawn considerable research interest from both academics and practitioners (Wood, 2000). Customer-based brand equity (CBBE) is a way of assessing the value of a brand in customers' minds. Branding can increase profitability in large and small-scale businesses by filling in gaps in customers' knowledge and by offering assurances. Customer-based brand equity is evaluating the consumer's response to a brand name (Keller 1993, Shocker et al. 1994). Therefore, the consumer-based brand equity is an asset of four dimensions that are brand awareness, brand associations, perceived quality and brand loyalty.

A brand can be defined as "a name, term, sing, symbol, or design, or combination of them which is intended to identify the goods and services of one seller or group of sellers and to differentiate them from those of competitors" (Kotler 1991; p. 442). These individual brand components are here called "brand identities" and their totality "the brand." Some basic memory principles can be used to understand knowledge about the brand and how it relates to brand equity.

Equity can be considered the sum total of values associated with a brand. These might include awareness, loyalty, and recognition. The greater the equity, the more likely customers will trust and choose the company's product or service. Additionally, equity capitalizes on normal psychological tendencies, such as the sometimes longer memory about negative experiences or the cognitive laziness that creates loyalty through a customer's unwillingness to choose unfamiliar products over familiar brand products.

The importance of knowledge in memory to consumer decision making has been well documented (Alba, Hutchinsion, and Lynch 1991). Understanding the content and structure of brand knowledge is important because they influence what comes to mind when a consumer thinks about a brand. For example, in considering a soft drink purchase, a consumer may think of Azam Cola because of its strong association with the product category. Customer knowledge most strongly linked to Azam Cola should also then come to mind, such as perceptions of its taste, sugar and caffeine content, or even recalled images from a recent advertising campaign or past product experiences.

Consistent with an associate network memory model, brand knowledge is conceptualized as consisting of a brand node in memory to which a variety of associations are linked. Given this conceptualization, the key question is what properties do the brand node and brand associations have? The relevant dimensions that distinguish brand knowledge and affect consumer response 
are the awareness of the brand and the favorability, strength, and uniqueness of the brand in consumer memory.

These dimensions are affected by other characteristics of and relationships among the brand associations. For example factors related to the type of brand association (such its level of abstraction and qualitative nature) and the congruity among brands associations, among others affect the favorability, strength, and uniqueness of brand associations. For the sake of simplification, emphasis is placed on the brand name, component of the brand identities, viewed as "that part of a brand which can be vocalized" (Kotler 1991, p. 442), though other components of the brand identities such as brand log or symbol) are considered also.

Building strong Customer-based brand equity is very crucial on firm performance and has been secrete for firm competition and survival, and has become a top priority for many strategic firms. The fact depicts that many business organizations have faced natural death due to poor branding and others are near to death to the same course.

Keller Kevin Lane (1993), views that a brand is said to have positive (negative) customer-based brand equity when consumers react more (less) favorable to an element of the marketing mix for the brand, they do to the same marketing mix element when it is attributed to a fictitiously named or unnamed version of the product or service.

However, despite the significance of strong customer-based brand equity on firm performance, limited studies were conducted to explore the dimensions of customer-based brand equity on firm performance in Tanzania. This created clear insight to the researcher to undergo this study, and study was very useful for further studies in this field.

There seem to be a consensus in the scholarly community that the study of customer based brand equity is of great importance in order to build and maintain a strong brand and it therefore seems relevant to the Azam Company which is a fast moving Company where it is important to be able to keep up with the competitors. Consequently the paper is intending to gauge customer's perception on brand awareness, brand associations, perceived quality and brand loyalty on Azam company product. Therefore, the paper is supportive on development of brands knowledge in Tanzania.

\section{RELATED LITERATURE: DIMENSIONS OF CUSTOMER-BASED BRAND EQUITY ON FIRM PERFORMANCE}

Brand equity has been extensively discussed in marketing literature over the past decade and there seem to be a consensus amongst the scholars that a brand has high brand equity when it generates positive connotations in the consumers' minds and is therefore likely to be the preferred purchase over other brands or non-branded products (Pappu et al, 2005; 143; Yoo et al 2001; 1; Kuhn et al 2008;41; Arvidsson 2006, ;189). Keller (1993;3) notes; that customer-based brand equity occurs when the consumer is familiar with the brand and holds some favorable, strong and unique brand associations in memory.

It has also been argued that brands with high brand equity can charge a premium price for their products (Kuhn et al 2008; 41; Arvidsson, 2006; 189). Nevertheless, exploring the dimensions of customer-based brand equity remains an important factor of brand management and can be used in order to guide marketing strategy and tactical decisions, to assess the extendibility of a 
brand, to evaluate the effectiveness of marketing decisions, and to track the brand's health compared to its competitors over time,' (Ailawadi 2003;.2).

Aaker adds to this idea and argues that as a part of its role in adding value for the customer, brand equity has the potential to add value for the firm by generating marginal cash flows in at least a dozen ways' $(1991 ; 16)$. For example sales promotions used to attract new customers and maintain current ones have a greater impact if the brand is familiar to the consumer. Secondly, when competing brands launch an innovative product, then a loyal customer base will buy some extra time to respond to this new challenge.

\section{METHODOLOGY}

The questionnaire is divided into two parts. The first is concerned with the demographic and the second part is thirty variables associated with the brand awareness, brand associations, perceived quality and brand loyalty. The data collection instrument is a structured questionnaire. A pool of 31 items compiled from the literature was incorporated in the questionnaire. Five variables were included for brand awareness, seventeen variables for brand association, five for perceived quality and four for brand loyalty. A Likert-scale of 1 to 5 was adopted for all the brand equity measures with the anchors 'strongly disagree' (1) and 'strongly agree' (5). The items were developed with reference to the empirical studies of Yoo and Donthu (2001) and Lassar et al (1995). The reason for referring to their scale development studies is that their scales are the most commonly accepted measure of customer-based brand equity (Washburn and Plank, 2002). Data Collection 100 questionnaires were sent to all parts of Dar es Salaam. Respondents were randomly selected. However, only 80 valid samples were used for the analysis. Data Analysis for the purposes of data analysis, SPSS was used to analyse the Cronbach's alpha, factor analysis and correlation.

\section{RESULT AND DISCUSSION}

\section{Demographic Characteristics}

The sample indicates a balance between males (63.8\%) and female (35.0\%). Majority of the respondents are those aged between 18-29 (52.5\%) aged between 30-41 (18.8\%) aged between 42-53 (13.8\%) aged between 54-65 (8.8\%) and over 65 (6.3\%). The breakdown of the study in terms of ages could be put in consideration since most of the ages are represented in the sample. 
INTERNATIONAL JOURNAL OF ACADEMIC RESEARCH IN BUSINESS AND SOCIAL SCIENCES

Vol. 8, No. 10, Oct. 2018, E-ISSN: 2222-6990 @ 2018 HRMARS

Table 4.1: Composition of the Respondents in Demographic terms

\begin{tabular}{|c|c|c|c|c|c|}
\hline Demographic & Rage & frequency & Percent & mean & Std. Dev \\
\hline \multirow[t]{2}{*}{ Gender } & Male & 51 & 63.8 & \multirow[t]{2}{*}{1.40} & \multirow[t]{2}{*}{1.40} \\
\hline & Female & 29 & 35.0 & & \\
\hline \multirow[t]{5}{*}{ Age } & $18-29$ & 42 & 52.5 & \multirow[t]{5}{*}{1.98} & \multirow[t]{5}{*}{1.98} \\
\hline & $30-41$ & 15 & 18.8 & & \\
\hline & $42-53$ & 11 & 13.8 & & \\
\hline & $54-65$ & 7 & 8.8 & & \\
\hline & Over 65 & 5 & 6.3 & & \\
\hline \multirow{3}{*}{$\begin{array}{l}\text { Consume of Azam } \\
\text { product }\end{array}$} & Less than five times & 13 & 16.3 & \multirow[t]{3}{*}{2.24} & \multirow[t]{3}{*}{0.716} \\
\hline & More than five times & 35 & 43.8 & & \\
\hline & infinity & 32 & 40.0 & & \\
\hline \multirow{16}{*}{$\begin{array}{l}\text { Favorable Azam } \\
\text { Product }\end{array}$} & Azam Juice & 67 & 83.8 & 1.00 & 0.000 \\
\hline & Azam Cola & 50 & 62.5 & 1.98 & 0.377 \\
\hline & Azam Marine & & & 2.97 & 0.164 \\
\hline & Azam Water & 59 & 73.8 & 4.00 & 0.000 \\
\hline & Azam Wheat flower & 53 & 66.3 & 5.00 & 0.000 \\
\hline & Azam Maize flower & 37 & 46.3 & 6.00 & 0.000 \\
\hline & Azam Television & 46 & 57.5 & 7.00 & 0.000 \\
\hline & Thuraya satellite Phone & 21 & 26.3 & 8.00 & 0.000 \\
\hline & Azam Coconut Milk & 41 & 51.3 & 9.00 & 0.000 \\
\hline & Azam Biscut & 53 & 66.3 & 10.00 & 0.000 \\
\hline & Azam Ice Cream & 62 & 77.5 & 11.00 & 0.000 \\
\hline & Azam Bread & 43 & 53.8 & 12.00 & 0.000 \\
\hline & Azam Milk & 41 & 51.3 & 13.00 & 0.000 \\
\hline & Azam Transport & 31 & 38.8 & 14.00 & 0.000 \\
\hline & Azam Plastic & 19 & 23.8 & 15.05 & 0.229 \\
\hline & Azam AICD & 7 & 8.8 & 16.00 & 0.000 \\
\hline
\end{tabular}

Source: Researcher's field data analysis 2018.

\section{Variable Description}

There are four main variables in this study namely brand awareness (BAW), brand associations(BAS), perceived quality (PQU) and brand loyalty (BLO). Since in each variable series of statement was developed to measure respondent perception on dimensions of customerbased brand equity on firm performance focus on Azam brands, this justifying of using likert scale is to get an overall measurement of a contributing variable (Likert 1932). Thus perception of Azam brand customer based products was measured on ordinal scale level of five-point likert scale i.e., 1=Strongly Agree, 2=Agree, 3=Neutral, 4=Disagree and 5=Strongly Disagree (Bowling 1997 and Burns \& Grove 1997). The study collected primary data from 50 dominance respondents from educational institutions like secondary schools, colleges, universities, business people retailers and laymen in Dar es Salaam in Tanzania. 
INTERNATIONAL JOURNAL OF ACADEMIC RESEARCH IN BUSINESS AND SOCIAL SCIENCES Vol. 8, No. 10, Oct. 2018, E-ISSN: 2222-6990 @ 2018 HRMARS

\section{Descriptive Statistics}

According to Trochin, (2006) a descriptive statistics are used to describe the basic features of the data in a study, with the purpose to present quantitative descriptions in simple summaries about the sample and the measures of the study in a sensible way. In descriptive statistics data set a measure commonly by measure of central tendency and measure of variability or dispersion. Babbie (2009) explain further Measures of central tendency include the mean, median and mode while measures of variability include the standard deviation (or variance), the minimum and maximum values of the variables, kurtosis and skewness. From table 4.2 below information regarding study variable brand awareness (BAW), brand associations (BAS), perceived quality (PQU) and brand loyalty (BLO). The data presented in sensible way based on the mean score and standard deviation. Below is the table summary;-

Table 4.2: Descriptive Statistics for Each Variable

\begin{tabular}{|l|l|l|}
\hline VARIABLE & MEAN & STANDARD DEVIATION \\
\hline Brand loyalty (BLO) & 14.05 & 5.037 \\
\hline Perceived quality (PQU) & 20.78 & 4.639 \\
\hline Brand associations (BAS) & 61.98 & 19.625 \\
\hline Brand awareness (BAW) & 17.16 & 5.753 \\
\hline
\end{tabular}

Source: Researcher's field data analysis 2018

\section{Correlation and Kaiser-Meyer-Olkin (KMO)}

According to Wang (2014) correlation measures the strength bivariate linear relationship of the variables. The correlation coefficient for each pair of variables is given by the correlation matrix (R-matrix). The purpose of correlation is to discover if there strong or weak; positive or negative relations between variables. As noted by Hair et al. (2009) the value of correlation can range between -1 and +1 . This means that, the values closer to either -1 or +1 indicate either strong negative or positive relationship respectively; also values closer to zero indicate weak relationship. But degrees of caution have to be established since problem of multi colinearity may exist, once variables have very strong relationship (Robert and William, 1975) and (Kock, Ned and Lynn, Gary, 2012). This problem hinders effective estimation in factor analysis. So caution is required in the correlation analysis since correlation is the basis for factor analysis. 
Table 4.3 Correlation Matrix for Ministered Variable

\begin{tabular}{|c|c|c|c|c|c|c|c|c|c|c|c|c|c|c|c|c|c|c|c|c|c|c|c|c|c|c|c|c|c|c|c|c|c|c|}
\hline \multicolumn{6}{|c|}{$\begin{array}{l}\text { Brand } \\
\text { awareness }\end{array}$} & \multicolumn{18}{|c|}{ Brand associations (BAS) } & \multicolumn{6}{|c|}{$\begin{array}{l}\text { Perceived } \\
\text { quality }\end{array}$} & \multicolumn{5}{|c|}{ Brand loyalty } \\
\hline & $\begin{array}{l}\text { B } \\
A \\
W \\
1\end{array}$ & $\begin{array}{l}\text { B } \\
\text { A } \\
W \\
2\end{array}$ & $\begin{array}{l}B \\
A \\
W \\
\mathbf{3}\end{array}$ & $\begin{array}{l}B \\
A \\
W \\
4\end{array}$ & $\begin{array}{l}B \\
A \\
W \\
5\end{array}$ & & $\begin{array}{l}B \\
A \\
S \\
1\end{array}$ & $\begin{array}{l}\text { B } \\
\text { A } \\
\text { S } \\
2\end{array}$ & $\begin{array}{l}B \\
A \\
S \\
3\end{array}$ & $\begin{array}{l}\text { B } \\
\text { A } \\
\text { S } \\
4\end{array}$ & $\begin{array}{l}\text { B } \\
\text { A } \\
\text { S } \\
5\end{array}$ & $\begin{array}{l}\text { B } \\
\text { A } \\
\text { S } \\
6\end{array}$ & $\begin{array}{l}\text { B } \\
A \\
S \\
7\end{array}$ & $\begin{array}{l}\text { B } \\
A \\
S \\
8\end{array}$ & $\begin{array}{l}\text { B } \\
A \\
S \\
9\end{array}$ & $\begin{array}{l}\text { B } \\
A \\
\text { S } \\
1 \\
0\end{array}$ & $\begin{array}{l}B \\
A \\
S \\
1 \\
1\end{array}$ & $\begin{array}{l}B \\
A \\
S \\
1 \\
2\end{array}$ & $\begin{array}{l}\text { B } \\
A \\
S \\
1 \\
3\end{array}$ & $\begin{array}{l}B \\
A \\
S \\
1 \\
4\end{array}$ & $\begin{array}{l}B \\
A \\
S \\
1 \\
5\end{array}$ & \begin{tabular}{|l} 
B \\
$A$ \\
S \\
1 \\
6
\end{tabular} & $\begin{array}{l}\text { B } \\
A \\
S \\
1 \\
7\end{array}$ & & $\begin{array}{l}P \\
Q \\
U \\
1\end{array}$ & $\begin{array}{l}\mathbf{P} \\
\mathbf{Q} \\
\mathbf{U} \\
\mathbf{2}\end{array}$ & $\begin{array}{l}\mathbf{P} \\
\mathbf{Q} \\
\mathbf{U} \\
\mathbf{3}\end{array}$ & $\begin{array}{l}P \\
Q \\
U \\
4\end{array}$ & $\begin{array}{l}\mathbf{P} \\
\mathbf{Q} \\
\mathbf{U} \\
\mathbf{5}\end{array}$ & & $\begin{array}{l}B \\
L \\
0 \\
1\end{array}$ & $\begin{array}{l}\text { B } \\
\text { L } \\
0 \\
2\end{array}$ & $\begin{array}{l}B \\
L \\
0 \\
3\end{array}$ & $\begin{array}{l}B \\
L \\
0 \\
4\end{array}$ \\
\hline $\begin{array}{l}B \\
A \\
W \\
1\end{array}$ & & $\begin{array}{l}. \\
1 \\
0 \\
9\end{array}$ & $\begin{array}{l}\cdot \\
1 \\
2 \\
6\end{array}$ & $\begin{array}{l}. \\
0 \\
4 \\
4\end{array}$ & $\begin{array}{l}. \\
0 \\
0 \\
0\end{array}$ & $\begin{array}{l}\text { B } \\
A \\
S \\
1\end{array}$ & & $\begin{array}{l}0 \\
5 \\
5\end{array}$ & $\begin{array}{l}0 \\
1 \\
3\end{array}$ & $\begin{array}{l}1 \\
6 \\
2\end{array}$ & $\begin{array}{l}0 \\
0 \\
2\end{array}$ & $\begin{array}{l}0 \\
0 \\
9\end{array}$ & $\begin{array}{l}0 \\
3 \\
9\end{array}$ & $\begin{array}{l}0 \\
1 \\
0\end{array}$ & $\begin{array}{l}. \\
4 \\
9 \\
1\end{array}$ & $\begin{array}{l}0 \\
3 \\
9\end{array}$ & $\begin{array}{l}5 \\
2 \\
7 \\
3\end{array}$ & $\begin{array}{l}3 \\
2 \\
8 \\
4\end{array}$ & $\begin{array}{l}. \\
4 \\
2 \\
6\end{array}$ & $\begin{array}{l}. \\
1 \\
9 \\
0\end{array}$ & $\begin{array}{l}0 \\
0 \\
3\end{array}$ & $\begin{array}{l}2 \\
4 \\
3\end{array}$ & $\begin{array}{l}. \\
2 \\
4 \\
5\end{array}$ & $\begin{array}{l}\mathbf{P} \\
\mathbf{Q} \\
\mathbf{U} \\
\mathbf{1}\end{array}$ & & $\begin{array}{l}0 \\
0 \\
0\end{array}$ & \begin{tabular}{|l|} 
\\
0 \\
0 \\
1
\end{tabular} & $\begin{array}{l}. \\
2 \\
8 \\
4\end{array}$ & $\begin{array}{l} \\
0 \\
3 \\
2\end{array}$ & $\begin{array}{l}B \\
L \\
0 \\
1\end{array}$ & & $\begin{array}{l}0 \\
0 \\
0 \\
0\end{array}$ & $\begin{array}{l}0 \\
2 \\
1\end{array}$ & $\begin{array}{l}0 \\
0 \\
2\end{array}$ \\
\hline $\begin{array}{l}\text { B } \\
\text { A } \\
\text { W } \\
2\end{array}$ & $\begin{array}{l}. \\
1 \\
0 \\
9\end{array}$ & & $\begin{array}{l}. \\
0 \\
0 \\
3\end{array}$ & $\begin{array}{l}. \\
1 \\
9 \\
6\end{array}$ & $\begin{array}{l}3 \\
3 \\
8 \\
0\end{array}$ & $\begin{array}{l}\text { B } \\
A \\
S \\
2\end{array}$ & $\begin{array}{l}. \\
0 \\
5 \\
5\end{array}$ & & $\begin{array}{l}0 \\
0 \\
9\end{array}$ & $\begin{array}{l}0 \\
0 \\
0 \\
7\end{array}$ & $\begin{array}{l}0 \\
0 \\
3\end{array}$ & $\begin{array}{l}\cdot \\
0 \\
1 \\
8\end{array}$ & $\begin{array}{l}0 \\
0 \\
0 \\
0\end{array}$ & $\begin{array}{l}0 \\
0 \\
4 \\
7\end{array}$ & $\begin{array}{l}2 \\
2 \\
5 \\
2\end{array}$ & $\begin{array}{l}. \\
0 \\
1 \\
2\end{array}$ & $\begin{array}{l}. \\
0 \\
3 \\
1\end{array}$ & $\begin{array}{l}5 \\
2 \\
8 \\
7\end{array}$ & $\begin{array}{l}. \\
0 \\
3 \\
8\end{array}$ & $\begin{array}{l}0 \\
0 \\
0 \\
1\end{array}$ & $\begin{array}{l}. \\
0 \\
0 \\
7\end{array}$ & $\begin{array}{l}0 \\
2 \\
8 \\
6\end{array}$ & $\begin{array}{l}. \\
2 \\
6 \\
0\end{array}$ & $\begin{array}{l}\mathbf{P} \\
\mathbf{Q} \\
\mathbf{U} \\
\mathbf{2}\end{array}$ & $\begin{array}{l}. \\
0 \\
0 \\
0\end{array}$ & & \begin{tabular}{|l|} 
\\
0 \\
0 \\
0
\end{tabular} & $\begin{array}{l}0 \\
0 \\
8 \\
0\end{array}$ & $\begin{array}{l}. \\
1 \\
3 \\
0\end{array}$ & $\begin{array}{l}\text { B } \\
\text { L } \\
0 \\
2\end{array}$ & $\begin{array}{l}. \\
0 \\
0 \\
0\end{array}$ & & $\begin{array}{l}. \\
0 \\
0 \\
0\end{array}$ & $\begin{array}{l}0 \\
0 \\
0 \\
0\end{array}$ \\
\hline $\begin{array}{l}\text { B } \\
\text { A } \\
\text { W } \\
\mathbf{3}\end{array}$ & $\begin{array}{l}\cdot \\
1 \\
2 \\
6\end{array}$ & $\begin{array}{l}. \\
0 \\
0 \\
3\end{array}$ & & $\begin{array}{l}. \\
0 \\
2 \\
1\end{array}$ & $\begin{array}{l}. \\
0 \\
3 \\
2\end{array}$ & $\begin{array}{l}\text { B } \\
A \\
\text { S } \\
3\end{array}$ & $\begin{array}{l}. \\
0 \\
1 \\
3\end{array}$ & $\begin{array}{l}. \\
0 \\
0 \\
9\end{array}$ & & $\begin{array}{l}1 \\
1 \\
1\end{array}$ & $\begin{array}{l}. \\
0 \\
2 \\
9\end{array}$ & $\begin{array}{l}\cdot \\
1 \\
1 \\
8\end{array}$ & $\begin{array}{l}0 \\
1 \\
8\end{array}$ & $\begin{array}{l}2 \\
2 \\
2 \\
5\end{array}$ & $\begin{array}{l}. \\
0 \\
4 \\
5\end{array}$ & $\begin{array}{l}. \\
0 \\
3 \\
6\end{array}$ & $\begin{array}{l}\cdot \\
4 \\
4 \\
4\end{array}$ & $\begin{array}{l}\cdot \\
1 \\
1 \\
3\end{array}$ & $\begin{array}{l}. \\
0 \\
7 \\
2\end{array}$ & $\begin{array}{l}0 \\
0 \\
2 \\
6\end{array}$ & $\begin{array}{l}\cdot \\
2 \\
2 \\
4\end{array}$ & $\begin{array}{l}3 \\
0 \\
3\end{array}$ & $\begin{array}{l}. \\
1 \\
6 \\
4\end{array}$ & $\begin{array}{l}\mathbf{P} \\
\mathbf{Q} \\
\mathbf{U} \\
\mathbf{3}\end{array}$ & $\begin{array}{l}. \\
0 \\
0 \\
1\end{array}$ & $\begin{array}{l}. \\
0 \\
0 \\
0\end{array}$ & & $\begin{array}{l}. \\
1 \\
1 \\
6\end{array}$ & $\begin{array}{l} \\
2 \\
7 \\
2\end{array}$ & $\begin{array}{l}\text { B } \\
\text { L } \\
0 \\
3\end{array}$ & $\begin{array}{l}. \\
0 \\
2 \\
1\end{array}$ & $\begin{array}{l}. \\
0 \\
0 \\
0\end{array}$ & & $\begin{array}{l}0 \\
1 \\
0\end{array}$ \\
\hline $\begin{array}{l}B \\
A \\
W \\
4\end{array}$ & $\begin{array}{l} \\
0 \\
4 \\
4\end{array}$ & $\begin{array}{l}. \\
1 \\
9 \\
6\end{array}$ & $\begin{array}{l}. \\
0 \\
1 \\
1\end{array}$ & & $\begin{array}{l}. \\
1 \\
0 \\
3\end{array}$ & $\begin{array}{l}\text { B } \\
A \\
S \\
4\end{array}$ & $\begin{array}{l} \\
1 \\
6 \\
2\end{array}$ & $\begin{array}{l}\cdot \\
0 \\
0 \\
7\end{array}$ & $\begin{array}{l}\cdot \\
1 \\
1 \\
1\end{array}$ & & $\begin{array}{l}. \\
2 \\
5 \\
2\end{array}$ & $\begin{array}{l}0 \\
0 \\
3 \\
3\end{array}$ & $\begin{array}{l}0 \\
0 \\
5 \\
4\end{array}$ & $\begin{array}{l}5 \\
1 \\
9 \\
5\end{array}$ & $\begin{array}{l}. \\
0 \\
1 \\
4\end{array}$ & $\begin{array}{l}2 \\
2 \\
4 \\
4\end{array}$ & $\begin{array}{l} \\
3 \\
9 \\
7\end{array}$ & $\begin{array}{l} \\
1 \\
1 \\
6\end{array}$ & $\begin{array}{l} \\
2 \\
7 \\
0\end{array}$ & $\begin{array}{l} \\
1 \\
5 \\
1\end{array}$ & $\begin{array}{l} \\
0 \\
7 \\
0\end{array}$ & $\begin{array}{l} \\
0 \\
2 \\
9\end{array}$ & $\begin{array}{l}. \\
1 \\
2 \\
7\end{array}$ & $\begin{array}{l}P \\
Q \\
U \\
4\end{array}$ & \begin{tabular}{|l|} 
\\
2 \\
8 \\
4
\end{tabular} & $\begin{array}{l} \\
0 \\
8 \\
0\end{array}$ & $\begin{array}{l}. \\
1 \\
1 \\
6\end{array}$ & & $\begin{array}{l}. \\
0 \\
0 \\
0\end{array}$ & \begin{tabular}{|l|} 
B \\
L \\
0 \\
4
\end{tabular} & $\begin{array}{l}. \\
0 \\
0 \\
2\end{array}$ & $\begin{array}{l} \\
0 \\
0 \\
0\end{array}$ & $\begin{array}{l}\cdot \\
0 \\
1 \\
0\end{array}$ & \\
\hline $\begin{array}{l}B \\
A \\
W \\
5\end{array}$ & $\begin{array}{l}0 \\
0 \\
0 \\
0\end{array}$ & $\begin{array}{l}. \\
3 \\
8 \\
0\end{array}$ & $\begin{array}{l}0 \\
0 \\
3 \\
2\end{array}$ & $\begin{array}{l}\cdot \\
1 \\
0 \\
3\end{array}$ & & $\begin{array}{l}\text { B } \\
\text { A } \\
\text { S } \\
5\end{array}$ & $\begin{array}{l}0 \\
0 \\
2 \\
\end{array}$ & $\begin{array}{l}0 \\
0 \\
3 \\
\end{array}$ & $\begin{array}{l}0 \\
2 \\
9\end{array}$ & $\begin{array}{l}2 \\
5 \\
2 \\
\end{array}$ & & $\begin{array}{l}0 \\
0 \\
0\end{array}$ & $\begin{array}{l}0 \\
0 \\
1\end{array}$ & $\begin{array}{l}0 \\
0 \\
0\end{array}$ & $\begin{array}{l}0 \\
4 \\
9 \\
\end{array}$ & $\begin{array}{l}0 \\
0 \\
0\end{array}$ & $\begin{array}{l}0 \\
0 \\
7\end{array}$ & $\begin{array}{l}0 \\
7 \\
6\end{array}$ & $\begin{array}{l}\cdot \\
1 \\
3 \\
8\end{array}$ & $\begin{array}{l}0 \\
1 \\
7 \\
\end{array}$ & $\begin{array}{l}0 \\
0 \\
7 \\
\end{array}$ & $\begin{array}{l}0 \\
4 \\
7 \\
\end{array}$ & $\begin{array}{l}. \\
0 \\
0 \\
8\end{array}$ & $\begin{array}{l}\mathbf{P} \\
\mathbf{Q} \\
\mathbf{U} \\
5\end{array}$ & $\begin{array}{l}. \\
0 \\
3 \\
2\end{array}$ & $\begin{array}{l}1 \\
3 \\
0\end{array}$ & $\begin{array}{l}2 \\
7 \\
2 \\
\end{array}$ & $\begin{array}{l}0 \\
0 \\
0\end{array}$ & & & & & & \\
\hline & & & & & & $\begin{array}{l}\text { B } \\
\text { A }\end{array}$ & . & . & $\dot{1}$ & 0 & . & & $\dot{0}$ & $\dot{0}$ & 2 & . & $\dot{0}$ & $\dot{1}$ & . & 4 & $\cdot$ & $\dot{0}$ & . & & & & & & & & & & & \\
\hline
\end{tabular}




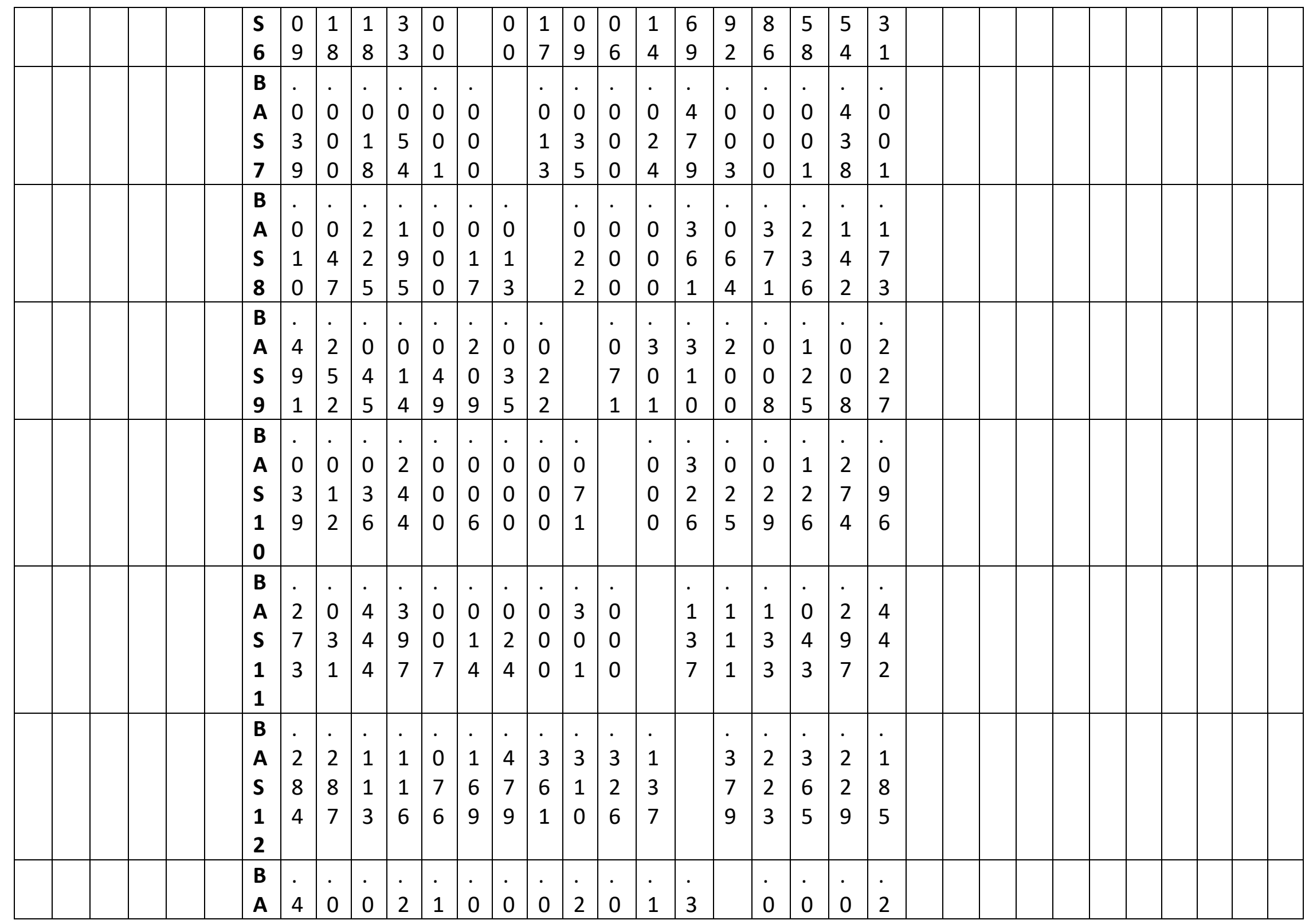




\section{INTERNATIONAL JOURNAL OF ACADEMIC RESEARCH IN BUSINESS AND SOCIAL SCIENCES}

Vol. 8, No. 10, Oct. 2018, E-ISSN: 2222-6990 @ 2018 HRMARS

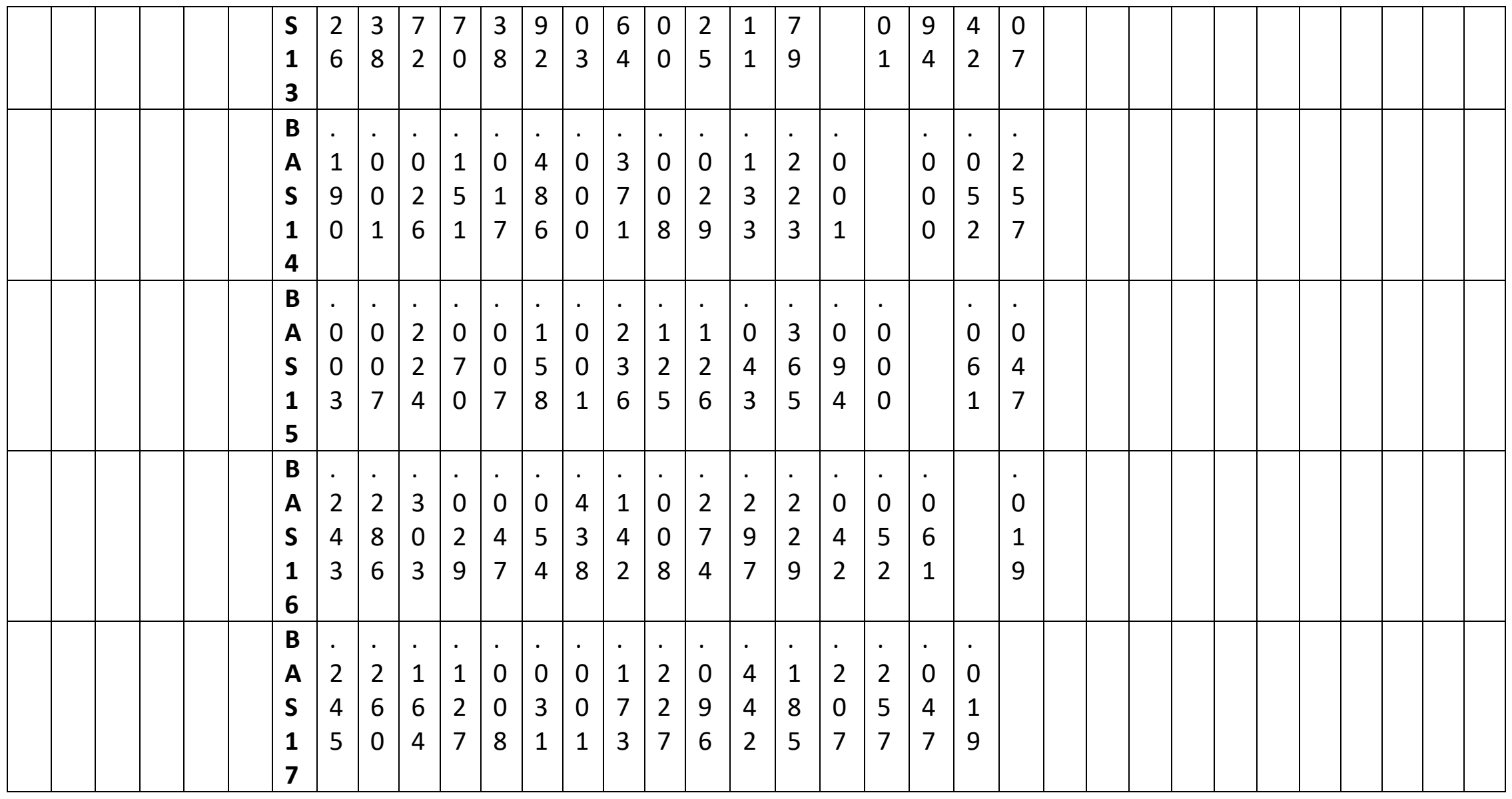

Source: Researcher's field data analysis 2018. 
In above matrix clusters of variables with high inter-correlations are represented, these clusters of variables could well be "manifestations of the same underlying variable" (Rietveld \& Van Hout 1993: 255). Revere to factor analysis correlation matrix for all manifested variable have to be generated, also they have to be inter-correlated but they should not correlate too highly (extreme multi collinearity and singularity) as this would cause difficulties in determining the unique contribution of the variables to a factor to other and last the correlation coefficients greater than 0.3 in absolute value are indicative of acceptable correlations (Field 2000: 444). Result shows that the correlation coefficients among the observed variables regarding brand awareness (BAW), brand associations (BAS), perceived quality (PQU) and brand loyalty (BLO), indicates that no variables which are highly correlated that can bring in the problem of extreme multi collinearity at determinant 0.00001 (Field 2000: 445).

Table 4.4 KMO and Bartlet Test for Ministered Variable

\begin{tabular}{|l|l|r|r|r|r|}
\hline \multicolumn{2}{|l|}{ KMO and Bartlett's Test } & BAW & \multicolumn{1}{l|}{ BAS } & \multicolumn{1}{l|}{ PQU } & \multicolumn{1}{l|}{ BLO } \\
\hline $\begin{array}{l}\text { Kaiser-Meyer-Olkin } \\
\text { Measure of Sampling } \\
\text { Adequacy. }\end{array}$ & KMO & 0.534 & 0.608 & 0.584 & 0.694 \\
\hline \multirow{2}{*}{ Bartlett's Test of Sphericity } & Approx. Chi-Square & 38.793 & 304.143 & 66.200 & 49.157 \\
\cline { 2 - 6 } & Df & 10 & 136 & 10 & 6 \\
\cline { 2 - 6 } & Sig. & 0.000 & 0.000 & 0.000 & 0.000 \\
\hline
\end{tabular}

Source: Researcher's field data analysis, 2018.

Kaiser-Meyer-Olkin (KMO) measures sampling adequacy. Its value ranges between 0 and 1. A value close to 0 indicates that the factor model will be inappropriate while a value closer to 1 will indicate the factor model is appropriate. Generally, KMO values greater than 0.5 are acceptable otherwise there is a need of expanding the sample size (Kaiser 1974). In our analysis KMO value are brand awareness (BAW) 0.534, brand associations (BAS) 0.608 , perceived quality (PQU) 0.584 and brand loyalty (BLO) 0.694 , which is fair and we are sure that our factor analysis model is appropriate.

As initiated by Bartlett (1937), Bartlett's test of sphericity is used to test the existence of an identity matrix in our correlation matrix. This identity matrix occurs when each pair of variables indicates zero correlation. Thus, if we reject the null hypothesis which states that the correlation matrix is an identity, then our factor model will be correct. Table 4.5 show that there is intercorrelation on manifested variable which has significance value of 0.000 for brand awareness (BAW), 0.000 for brand associations (BAS), 0.000 for perceived quality (PQU) and 0.000 for brand loyalty (BLO). This means that the test was significant value of 0.000 is less than 0.05 thus, factor analysis will be applicable for our data. 
INTERNATIONAL JOURNAL OF ACADEMIC RESEARCH IN BUSINESS AND SOCIAL SCIENCES Vol. 8, No. 10, Oct. 2018, E-ISSN: 2222-6990 @ 2018 HRMARS

\section{Reliability Measure of Variables}

Any research based on measurement must be concerned with the accuracy or dependability. In this study a likert survey instruments were used, it is essential to discern that the instrument have to be elicit consistent and reliable response even if were replaced with other similar questions. Such kind of instrument which generated from such a set of questions that return a stable response, then your variable is said to be reliable. As noted by Thorndike, Cunningham, Thorndike, \& Hagen, (1991) reliability refers to the accuracy and precision of a measurement procedure. Reliability comes to the forefront when variables developed from summated scales are used as predictor components in objective models; it is a function of properties of the underlying construct being measured, the test itself, the groups being assessed, the testing environment, and the purpose of assessment. The measurement of reliability is Cronbach's alpha is an index of reliability associated with the variation accounted for by the true score of the underlying construct (Hatcher, 1994). As developed by Cronbach, (1951). Alpha coefficient ranges in value from 0 to 1 and may be used to describe the reliability of factors extracted from dichotomous. The higher the score, the more reliable the generated scale is. Nunnaly (1978) and Welman and Kruger (2001:141), has indicated 0.7 to be an acceptable reliability coefficient but lower thresholds are sometimes used in the literature, but other scholar such as Zidmund, Babin, Carr \& Griff (2010) argue that acceptable levels of reliability depend on the purpose of the instrument and research purposes can be as low as 0.60 . However as noted by Parasuraman et al (1985) that in some situation where by a diagnostic instrument used for making decisions about individuals for instance a psychological measure Cronbach alpha should be much higher as 0.95 .

Table 4.5 Cronbach's Alpha Reliability Measure for All Variables

\begin{tabular}{|l|r|r|r|}
\hline Variables & N of Items & N of observations & Cronbach's Alpha \\
\hline Brand Awareness (BAW) & 5 & 80 & 0.458 \\
\hline Brand Awareness (BAS) & 17 & 80 & 0.784 \\
\hline Brand Awareness (PQU) & 5 & 80 & 0.622 \\
\hline Brand Awareness (BLO) & 4 & 80 & 0.666 \\
\hline Overall Alpha & $\mathbf{3 1}$ & $\mathbf{8 0}$ & $\mathbf{0 . 8 5 7}$ \\
\hline
\end{tabular}

Source: Researcher's field data analysis, 2018.

Table 4.5 above provides the Cronbach's alpha for each observed variable regarding challenges facing procurement functions in Tanzania. The overall Cronbach's alpha coefficient is 0.789 indicating a good reliability.

\section{Component Factor Analysis}

Factor analysis is a multivariate statistical technique for data reduction. It compresses sets of complex data without losing data integrity, to form reduced set of factors, which are assumed to represent the observed variables under consideration. Gorsuch (1983:4) more that factor analysis helps reduce a number of variables to a meaningful, interpretable and manageable set. 
In this study factor analysis will be used to establish whether the variables: Positive Influences of customer based brand equity (PCI) and Negative Influences of customer based brand equity $(\mathrm{NCl})$. Therefore, all factor loadings must be statistically significant at a minimum to confirm the discriminated validity of the measuring instrument used in the study. In this study, the sample size was 81 which are confirmed by Camrey and Lee (1992), Garson (2008) and Noruis (2005) in terms of the factor analysis sample size rule on number of constrain. In this study, the principalcomponent exploratory factor analysis with the support of statistical package SPSS 17.0 was adopted so as to obtain sound and clean solutions for our problem. Below is the table 4.6 shown result of factors analysis. 
INTERNATIONAL JOURNAL OF ACADEMIC RESEARCH IN BUSINESS AND SOCIAL SCIENCES

Vol. 8, No. 10, Oct. 2018, E-ISSN: 2222-6990 @ 2018 HRMARS

Table 4.6 Factor Loadings on Perception of African Multinational Enterprises in Tanzania

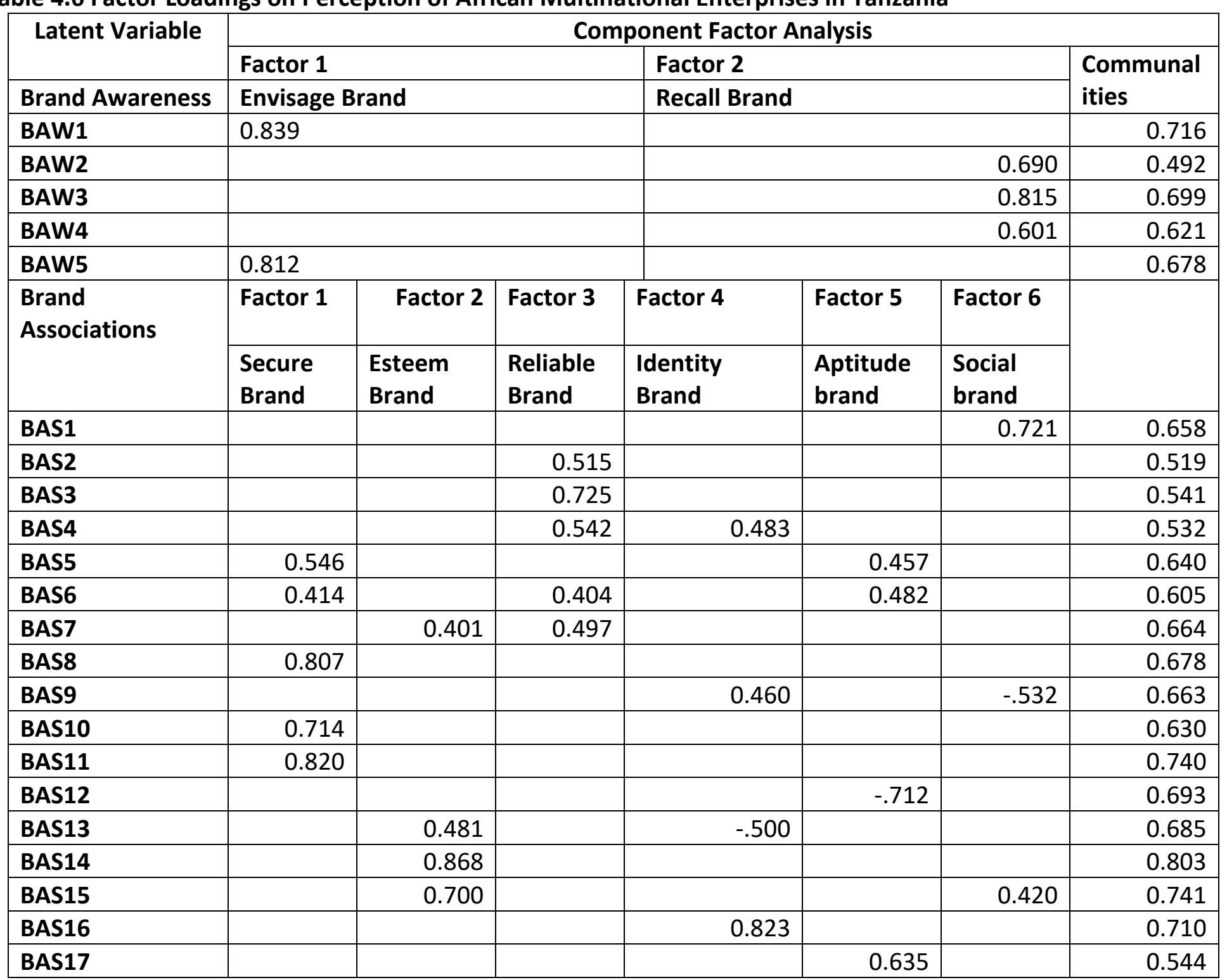


INTERNATIONAL JOURNAL OF ACADEMIC RESEARCH IN BUSINESS AND SOCIAL SCIENCES

Vol. 8, No. 10, Oct. 2018, E-ISSN: 2222-6990 @ 2018 HRMARS

\begin{tabular}{|c|c|c|c|}
\hline \multirow[t]{2}{*}{ Perceived Quality } & Factor 1 & Factor 2 & \\
\hline & Reliable Brand & Informed Brand & \\
\hline PQU1 & 0.816 & & 0.674 \\
\hline PQU2 & 0.826 & & 0.692 \\
\hline PQU3 & 0.700 & & 0.492 \\
\hline PQU4 & & 0.857 & 0.738 \\
\hline PQU5 & & 0.852 & 0.736 \\
\hline \multirow{2}{*}{$\begin{array}{l}\text { Brand Equity } \\
\text { Construct }\end{array}$} & \multicolumn{2}{|l|}{ Factor 1} & \\
\hline & \multicolumn{2}{|l|}{ Brand Loyalty } & \\
\hline BLO1 & 0.710 & & 0.504 \\
\hline BLO2 & 0.822 & & 0.676 \\
\hline BLO3 & 0.665 & & 0.443 \\
\hline BLO4 & 0.673 & & 0.452 \\
\hline BLO5 & 0.710 & & 0.504 \\
\hline
\end{tabular}

Source: Researcher's field data analysis 2018. 
The component factor analysis result shown in table 4.6 reveals that out of five items expected to measure brand awareness give new two factors. two items loading in factor one (1) BAW1 and BAW5 this means that respondents viewed these items as measure of a single construct renamed as and labeled Envisage Brand, envisage brand is the brand that creates mental picture to the customers thus Azam brand was regarded as envisage because it has strong imaginative power. Three items loading in factor two (2) BAW2 BAW3 and BAW4 this means that respondents viewed these items as measure of a single construct renamed as and labeled Recall Brand. Recall brand is the brand which is well connected with a product type or class of products by consumers. Also communalities on all variables are considered to be more that $60 \%$.

The component factor analysis result shown in table 4.6 reveals that out of seventeen items expected to measure brand association give new six factors. Five Items loading in factor one (1) BAS5, BAS6, BAS8, BAS10 and BAS11. This means that respondents viewed these items as measure of a single construct renamed as and labeled Secure Brand; secure brand is the brand that ensures health security to the customers thus Azam is perceived to be secure brand as it is health centered brand.

Four items loading in factor two (2) BAS7, BAS13, BAS14 and BAS15 this means that respondents viewed these items as measure of a single construct renamed as and labeled Esteem Brand. Esteem Brand or goodwill is customers' respect for and attraction to a particular brand. It's not to be confused with brand awareness or familiarity, which is the level of recognition of a brand. While a brand might be well known (a good thing), it may not in fact be well regarded (not a good thing). Esteem Brand is about the favorable sentiment toward a brand.

Five Items loading in factor three (3) BAS2, BAS3, BAS4, BAS6 and BAS7, this means that respondents viewed these items as measure of a single construct renamed as and labeled Reliable Brand. The reliable brand offers comparable quality at lower prices, and enables customer to meet and exceed his or her expectations to such brand. I appreciate that the Reliable Brand prices remain consistent. And they are less expensive than other brands while still being quality products. The products fit my budget and help us keep the facilities in great shape. (Debbie Mayberry) President QES Solutions Inc.

Four Items loading in factor four (4) BAS4, BAS8, BAS13 and BAS16 this means that respondents viewed these items as measure of a single construct renamed as and labeled Identity Brand. Azam Brand is viewed as Identity Brand because it coordinates all forms of media both online and in print with matching graphics, phrases, fonts, images and ideas to ensure the company is always represented in a professional manner.

Four Items loading in factor five (5) BAS5, BAS6, BAS11 and BAS17 this means that respondents viewed these items as measure of a single construct renamed as and labeled Aptitude brand. Aptitude brand refers to the strategic brand with well Design positioning which identify and introduce itself. 
Three Items loading in factor six (6) BAS1, BAS9 and BAS15 this means that respondents viewed these items as measure of a single construct renamed as and labeled Social brand. A social brand is any company, product, or individual that uses social technologies to communicate with social customers, their partners and constituencies, or the general public. Also communalities on all variables are considered to be more that $60 \%$.

The component factor analysis result shown in table 4.6 reveals that out of five items expected to Perceived Quality give new two factors. Three Items loading in factor one (1) PQU1, PQU2, and PQU3. This means that respondents viewed these items as measure of a single construct renamed as and labeled Reliable Brand. Two items loading in factor two (2) PQU4 and PQU5, this means that respondents viewed these items as measure of a single construct renamed as and labeled Informed Brand. An informed brand means a brand which its information's are everywhere, most people have full knowledge on every information about the brand. Also communalities on all variables are considered to be more that $60 \%$.

The component factor analysis result shown in table 4.6 reveals that out of five items expected to measure Brand Equity Construct give only one factor. Five Items loading in factor one (1) BLO1, BLO2, BLO3, BLO4 and BLO5 this means that respondents viewed these items as measure of a single construct renamed as and labeled Brand Loyalty. Brand loyalty is a result of consumer behavior and is affected by a person's preferences. Loyal customers will consistently purchase products from their preferred brands, regardless of convenience or price. Azam brand is perceived as Brand loyalty due to the tendency of her customers to preferences on purchasing frequently Azam products than any other brand.

\section{MANAGERIAL IMPLICATION AND CONCLUSION Managerial Implication}

This paper has broadly and systematically analyzed four principle questions; first is customers' perception on brand loyalty, second is the customers' perception on perceived quality, third is customers' perception on brand associations and the last one is customers' perception on brand awareness towards Azam brand.

\section{Brand Awareness}

Keller (2003, p.76) defines awareness as " the customers' ability to recall and recognize the brand as reflected by their ability to identify the brand under different conditions and to link the brand name, logo, symbol, and so forth to certain associations in memory". Azam brand in Tanzania is the most popular brand and many customers purchase its products because the awareness of the brand is very high, many customers showed their high level of memorizing Azam brand and its products.

\section{Brand Association}

Aaker (1996) conceptualizes brand awareness that must precede brand associations. That is where a consumer must first be aware of the brand in order to develop a set of associations (Washburn and Plank, 2002). Healthy assurances, goodwill, comparable quality at lower prices 
INTERNATIONAL JOURNAL OF ACADEMIC RESEARCH IN BUSINESS AND SOCIAL SCIENCES

Vol. 8, No. 10, Oct. 2018, E-ISSN: 2222-6990 @ 2018 HRMARS

are some of the reasons why many customers prefer Azam brand products. Azam also coordinates all forms of media both online and printing, together with a very well organized and designed positioning and take a good advantage of social media technology to communicate to its customers. This has made it brand to win customers mind and be one of the most successful brand in Tanzania.

\section{Perceived Quality}

Perceived quality is related to a consumer's judgment of a product or brand's overall superiority or excellence (Zeithaml, 1988). The quality of the brand matters and for Azam brand, customers are happy and satisfied with the quality. High perceived quality allows for consumers to be convinced about buying the brand; for differentiation of the brand from competition; and for the firm to charge a premium price and then extend the brand (Aaker, 1991). Perceived quality is hence formed to judge the overall quality of a product/service. Boulding et al. (1993) argued that quality is directly influenced by perceptions. Consumers use the quality attributes to 'infer' quality of an unfamiliar product. It is therefore important to understand the relevant quality attributes are with regard to brand equity.

\section{Brand loyalty}

Finally, Aaker (1991, p. 39) defines the fourth dimension, brand loyalty, as "the attachment that a customer has to a brand". Loyalty is a core dimension of brand equity. Aaker (1991, p. 39) defines brand loyalty as the attachment that a customer has to a brand and customers have shown how attached to Azam brand are and this created the loyalty and for marketers this is a very big advantage. Gil et al. (2007) have shown that loyalty is an important dimension of equity; and if brand loyalty is established, then brand equity will be the result. When a customer is loyal to a product or a brand, they consider it as their first option or choice and they are not influenced or affected by the strategies that are employed by competitors to lure them or get their attention (Tong and Hawley, 2009

\section{Conclusion Base on Regression Analysis.}

In order to arrive on scientific conclusion regression analysis was used, below $w$ is table and discussion. Note that: EBL stands for Equity Brand Loyalty, EBA stands for Equity Brand Awareness, EPQU stands for Equity Perceived Quality, EBAS stands for Equity Brand Association and CON stands for Consumer.

Below is the Regression summary on Table 6 
INTERNATIONAL JOURNAL OF ACADEMIC RESEARCH IN BUSINESS AND SOCIAL SCIENCES Vol. 8, No. 10, Oct. 2018, E-ISSN: 2222-6990 @ 2018 HRMARS

Table 6: Regression summary

\begin{tabular}{|l|r|r|r|lr|}
\hline \multicolumn{9}{|c|}{ Model Summary } \\
\hline Model & $\mathrm{R}$ & $\begin{array}{c}\mathrm{R} \\
\text { Square }\end{array}$ & \multicolumn{1}{|l|}{ Adjusted R Square } & \multicolumn{2}{|l|}{$\begin{array}{l}\text { Std. Error of the } \\
\text { Estimate }\end{array}$} \\
\hline 1 & $.317^{\mathrm{a}}$ & .101 & .013 & & .761 \\
\hline
\end{tabular}

a. Predictors: (Constant), EBL, EBAW, EPQU, EBAS

\begin{tabular}{|l|r|r|r|r|r|}
\hline \multicolumn{7}{|c|}{ ANOVA $^{\text {a }}$} \\
\hline Model & Sum of Squares & df & Mean Square & F & Sig. \\
\hline 1Regression & 2.652 & 4 & .663 & 1.146 & $.348^{\text {a }}$ \\
\hline Residual & 23.717 & 41 & .578 & & \\
\hline Total & 26.370 & 45 & & & \\
\hline
\end{tabular}

a. Dependent Variable: CON b. Predictors: (Constant), EBL, EBAW, EPQU, EBAS

\begin{tabular}{|c|c|c|c|c|c|}
\hline \multicolumn{6}{|c|}{ Coefficients $^{a}$} \\
\hline \multirow[t]{2}{*}{ Model } & \multicolumn{2}{|c|}{ Unstandardized Coefficients } & \multirow{2}{*}{$\begin{array}{c}\text { Standardized Coefficients } \\
\text { Beta }\end{array}$} & \multirow[t]{2}{*}{$\mathrm{t}$} & \multirow{2}{*}{ Sig. } \\
\hline & B & Std. Error & & & \\
\hline (Constant) & 1.911 & 1.060 & & 1.803 & .079 \\
\hline EBAW & -.005 & .037 & -.021 & -.137 & .892 \\
\hline EBAS & -.012 & .020 & -.153 & -.615 & .542 \\
\hline EPQU & .003 & .051 & .010 & .052 & .959 \\
\hline EBL & .079 & .042 & .405 & 1.898 & .065 \\
\hline
\end{tabular}

a. Dependent Variable: CON

Source: Authors based on analysis in SPSS.20.

The " $R$ " value is the correlation coefficient between the dependent variable and the independent variables. According to the Model Summary, the value of correlation coefficient " $R$ " of four independent variables Predictors (Constant), EBL, EBAW, EPQU and EBAS with the dependent variable (CON) is 0.317 . Therefore, there is positive and moderate correlation between four independent variables and dependent variable.

Besides that, Model Summary also indicates the coefficient of determination ( $R$ square) which can help in explaining variance. The $R$ square figure of the three independent variables is 0.13 . These also mean that independent variables (EBL, EBAW, EPQU and EBAS) can explain $1.3 \%$ of the variation in dependent variable (CON). However, it $98.7 \%$ (100\% - 1.3\%) still remain unexplained in this research. In other words, there are other additional variables that are important in explaining CON that have not been considered in this research (these could be; income price, attitude, fashion, status and others) which can be researched further by other scholars.

Based on (ANOVA), the p-value is 0.345 which is greater than alpha value 0.05 . Besides that, the $F$ statistic is significant at the value of 1.146. Therefore, the model is a good descriptor of the relation between the dependent and predictor variables. As a result, the independent variables (EBL, EBAW, EPQU and EBAS) are statistically significant to explain the variance in (brand performance). Thus Null hypothesis $\left(H_{0}\right)$ is rejected and alternative hypothesis $\left(H_{1}\right)$ is accepted. 
INTERNATIONAL JOURNAL OF ACADEMIC RESEARCH IN BUSINESS AND SOCIAL SCIENCES

Vol. 8, No. 10, Oct. 2018, E-ISSN: 2222-6990 @ 2018 HRMARS

The four independent variables are the factors that determine brand performance. This can be expressed in the Regression equation in this format below:

$\mathbf{Y}=\mathbf{a}+\mathbf{b}_{1} \mathbf{X}_{1}+\mathbf{b}_{2} \mathbf{X}_{2}+\mathbf{b}_{3} \mathbf{X}_{3}$

Based on the Coefficients, the regression equation for the customer satisfaction is:

Con $=1.911+(0.37 \times-0.005)+(0.020 X-0.012)+(0.051 X 0.003)+(0.042 \times 0.079)$.

From the Coefficient's table, location of EBL is the first and most significant independent variable in this research since its t-value is 1.898 and $p$-value is 0.065 , which is greater than alpha value 0.05 . This also shows that equity brand loyalty (EBL) of Azam products is significance to predict Consumer Satisfaction (CON). Besides that, Equity brand loyalty (EBL) is the predictor variable that contributes the highest to the variation of the Consumer Satisfaction (CON) because Beta value (under standardized coefficients) for this predictor variable is the largest (0.405) if compared to other predictor variables (EBAW, EBAS, EPQU).

Equity perceived quality (EPQU) is significant independent variable where it carries out the t-value 0.052 and the $p$-value 0.959 , which is greater than the alpha value 0.05 . This shows that Equity perceived quality (EPQU) is significant to predict consumer satisfaction (CON). In addition, Equity perceived quality (EPQU) contributes Beta value (under standardized coefficients) for this predictor variable 0.010

Equity Brand Association (EBAS) is another significant independent variable where as its t-value is 0.615 and $p$-value is 0.542 , this is less than alpha value of 0.05 . This represents that the Equity Brand Association (EBAS) is not significant to predict Consumer Satisfaction (CON). Besides, Equity Brand Association (EBAS) contributes the third highest to the variation of the Consumer Satisfaction (CON) its Beta value (under standardized coefficients) for this predictor variable is minus $(-0.153)$.

Equity Brand Awareness (EBAW) is the last significant independent variable where as its t-value is 0.137 and $p$-value is 0.892 , this is less than alpha value of 0.05 . This represents that the Equity Brand Awareness (EBAW) is not significant to predict Consumer Satisfaction (CON). Equity Brand Awareness (EBAW) contributes the least highest to the variation of the Consumer Satisfaction (CON) where as its Beta value (under standardized coefficients) for this predictor variable is minus (-0.021).

Generally, the results indicate that Equity brand loyalty (EBL) and Equity perceived quality (EPQU) have a significant relationship with Consumer Satisfaction (CON). However, there is no significant relationship between Equity Brand Association (EBAS) and Equity Brand Awareness (EBAW) with Consumer Satisfaction (CON)

\section{Recommendation}

From the findings, the researchers of the study found that consumer satisfaction has significance relationship with brand loyalty and perceived quality. In another word the firm performance of Azam as a Brand depends much on how consumer perceived the quality of its product and the loyalty of the Brand to consumers. Moreover the insignificant relationship of brand awareness and brand associations with consumer satisfaction has made the study to have room for further studies. There are other variables for firm performance which relate to consumers than those explained above. Most consumers seems to have very little awareness of the brand and how brand associate itself but due to successful positioning of Azam Brand consumers trust its products above other Brands. 
However the study is limited as only Brand Equity explained and leaves other variables like price, fashion attitudes and so on untouched.

Consumer-based brand equity application in terms of brand will provide quantitative measures to the success of the brand building efforts, in spite the fact that equity cannot be built in short term but long term with carefully designed marketing strategies. No one would deny that brands, now more than ever, are owned by consumers; they shape them, they use them, and they even market and promote them. Consumers have become the storytellers, and the individual power of each unique story is part of the brand's equity. (Baalbaki and Guzman, 2016). Although brand is not the only measure for the firm performance, the study shows that it is the strongest tool for the long term business success if it is well designed, established and maintained.

\section{References}

1. Aaker, D. A. (1991). Managing Brand Equity,Free Press, New York.

2. Aaker, D. A. (1991), Managing Brand Equity. New York: The Free Press.

3. Aaker, D. A. (1996), Building strong brands, Free Press: New York, NY

4. Ailawadi, K., Lehmann, D., and Neslin, S. (2003), "Revenue premium as an outcome measure of brand equity," Journal of Marketing, 67(4), 1-17.

5. Alba, Hutchinsion, and. Lynch, Jr. (1991), "Memory and Decision Making," in Handbook of Con-sumer Theory and Research, Harold H. Kassarjian and Thomas S. Robertson, eds. Englewood Cliffs, NJ: Pren-tice-Hall, Inc., 1-49.

6. Arvidsson, Adam., (2006). Brand Value. Brand Management, 13 (3),pp.188-192 brand equity", Journal of Marketing, Vol. 57, January, pp. 1-22

7. Baalbaki S. and Guzman F. (2016) Consumer-based brand equity. In F. D. Riley, J. Singh, \& C. Blankson (Eds.), The Routledge Companion to Contemporary Brand Management (pp 32-47) Rotledge.

8. Babbie, Earl R. (2009). The Practice of Social Research (12 $2^{\text {th }}$ Ed.). Wadsworth.

9. Bartlett, M. S. 1937. Properties of Sufficiency and Statistical Tests. Proc. Roy. Soc. London Ser. (160) 268-282.

10. Bowling A., (1997). Research Methods in Health. Open University Press, Buckingham

11. Burns N. \& Grove SK., (1997) The Practice of Nursing Research Conduct, Critique, \& Utilization. W.B. Saunders and Co. Philadelphia.

12. Camrey, A. L., \& Lee, H. B. (1992). A first Course in Factor Analysis. Hillsdale, NJ: Erlbaum.

13. Cronbach, L. J. (1951). Coefficient alpha and the internal structure of tests. Psychometrika. (16) 297-334.

14. Field, A. P. (2000). Discovering statistics using SPSS for Windows: Advanced techniques for the beginner. London: Sage.

15. Gil, R. B., Adres, E. F. and Salinas, E. M. (2007), "Family as a source of consumer-based brand equity", Journal of Product and Brand Management, 16 (3): 188-99.

16. Garson, D.G. (2008). Factor analysis: State notes. North Carolina State University Public Administration Program. 
INTERNATIONAL JOURNAL OF ACADEMIC RESEARCH IN BUSINESS AND SOCIAL SCIENCES Vol. 8, No. 10, Oct. 2018, E-ISSN: 2222-6990 @ 2018 HRMARS

17. Gorsuch, R.L. (1983). Factor analysis. $2^{\text {nd }}$ edition. Hillsdale, NJ: Erlbaum.

18. Hair, J. f., Jr, William C. Blackbarry J. Babin, and Rolph E. Anderson (2009) Multivariate data analysis, Pearson., upper saddle river Boston Columbus San Francisco

19. Hatcher, L. (1994). A step-by-step approach to using the SAS(R) system for factor analysis and structural equation modeling. Cary, NC: SAS Institute

20. Kaiser, H.F. (1974). An index of factorial simplicity. Psychometrika, 39, 31-36.

21. Keller, K. L., (1993), "Conceptualizing, Measuring, and Managing Customer- Based Brand Equity," Journal of Marketing, 57(1), 1-22. Equity", Journal of Marketing, Vol. 57, January, pp. 1-22. Improving the Measurement - Empirical Evidence," Journal of Product and Brand Management, 14 (3). 143-154.

22. Keller, K. L. (2003), Strategic brand management: building, measuring, and managing brand equity (2nd edn), Prentice Hall: Upper Saddle River, NJ

23. King, cited in Aaker, (1991), p.1 King, Ceridwyn, Grace, Debra Exploring the role of employees in the delivery of the brand: a case study approach. Qualitative Market Research: An International Journal.

24. Kock, Ned and Lynn, Gary S. (2012). "Lateral Collinearity and Misleading Results in VarianceBased SEM: An Illustration and Recommendations," Journal of the Association for Information Systems: Vol. 13: Iss. 7, Article 2.

25. Kotler, P.H. (1991), Marketing Management, Analysis, Planning, and Control, 8th ed.,

26. Kuhn, K.L, Alpert, F and Pope, N.K.K., (2008). An application of Keller's brand equity model in a B2B context, Qualitative Market Research: an International Journal, 11 (1), pp. 40-58

27. Lassar, Walfried, Banwari Mittal, and Sharma Arun (1995), "Measuring Customer-Based Brand Equity," Journal of Consumer Marketing, 12 (4), 11-19.

28. Noruis, M.J. (2005). SPSS 13.0 Statistical procedures companion. Chicago: SPSS, Inc.

29. Nunnaly, J. (1978). Psychometric theory. New York: McGraw-Hill.

30. Pappu, R., Quester, P.G. and Cooksey, R. (2005), "Consumer-Based Brand Equity: Improving the Measurement - Empirical Evidence," Journal of Product and Brand Management 14(3), 143-154. Prentice-Hall, Englewood Cliffs, NJ. Stockholders," Advertising Age 65 (30). 18.

31. Parasuraman, A., Zeithaml, V. A., and Berry, L. L. (1985). A conceptual model of service Quality and its implications for future research, Journal of Marketing, (49)41-50.

32. Rietveld, T. \& Van Hout, R. (1993). Statistical Techniques for the Study of Language and Language Behaviour. Mouton de Gruyter. New York

33. Robert Mason And William G. Brown (1975). Multicollinearity Problems and Ridge Regression in Sociological Models1. Social science research 4, 135-149

34. Thorndike, R. M., Cunningham, G. K., Thorndike, R. L., \& Hagen E. P. (1991). Measurement and evaluation in psychology and education. New York: Macmillan Publishing Company

35. Tong, X. and Hawley, J. M. (2009), "Measuring customer-based brand equity: empirical evidence from the sportswear market in China", Journal of Product and Brand Management, 18 (4): 262-71

36. Trochin, W.M.K. (2006). Research methods knowledge base. [Online]. Available: www.socialresearchmethods.net [Accessed: September 2011] 
INTERNATIONAL JOURNAL OF ACADEMIC RESEARCH IN BUSINESS AND SOCIAL SCIENCES

Vol. 8, No. 10, Oct. 2018, E-ISSN: 2222-6990 @ 2018 HRMARS

37. Wang (2014) Correlation Analysis. [Online]. Available:, http://www.stat.wmich.edu/wang/216/notes/Correlation handout.pdf

38. Washburn, J.H. and Plank, R.E. (2002), "Measuring Brand Equity: an Evaluation of a ConsumerBased Brand Equity Scale," Journal of Marketing Theory and Practice 10(1), 46-61.

39. Welman J. and Krugar S. J. (2001) Research methodology. New York: Oxford University Express.

40. Wood, L. (2000). "Brands and Brand Equity: Definition and Management," Journal of Management Decision, 38 (9). 662-669. Brand Equity: Relationships and Implications for International Marketing," Journal of International Business Studies, 38 (5). 726- 745

41. Yoo, B. \& Donthu, N. (2001). "Developing and Validating a Multidimensional

Consumer based Brand Equity Scale," Journal of Business Research, 52 (1). 1-14.

42. Zeithaml,V. A. (1988). "Consumer Perceptions of Price, Quality, and Value: A Means-end Model and Synthesis of Evidence," Journal of Marketing, 52 (3)

43.Zikmund, W. G., Babin, B. J., Carr, J. C. \& Griffin, M. (2010). Business research methods. $8^{\text {th }}$ edition. Singapore: South-Western Cengage Learning 